\title{
化粧品における応用
}

\author{
光 井 武 夫 \\ 資生堂研究所（横浜市港北区新羽町 1050)
}

\section{Application of Surfactants in Cosmetic Industries}

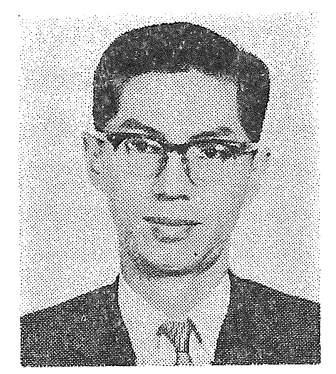

Takeo Mitsui

Shiseido Laboratory (Nippa-chō, Kōhhoku-ku, Yokohama)

化粧品工業では界面活性剤の種々の機能が多方面にわ たって利用されている。

たとえば,クリームや乳液のような乳化製品の場合は 乳化剂として, 透明な化粧水の場合は香料や薬剈や油分 の可溶化剤として, 粉末のはいった口紅やファンデーシ ヨン類のようなメーキャップ製品の場合は分散剂として 用いられる。その他洗浄剂, 湿潤剤, 結晶析出防止剤, 染料助剤などとして利用される場合も多い。

戦後界面活性剈の発達により化粧品の品質も飛躍的に 向上した。化粧品工業に打ける界面活性剂の使用量も 年々増加しているが, 反面界面活性剂によってもたらさ れる問題点も少なくない。以下化粧品工業に打ける界面 活性剤の利用状況とその問題点について概説する。

\section{1 乳化剂として}

化粧品にはクリームや乳液をはじめとして多くのエマ ルションが用いられている。クリームや乳液は基礎化粧 料として膚のよごれを落とし, 膚を整え, しっとりとし たなめらかさを与え, またメーキャップの下地としての 働きをする。

化粧品にエマルションを用いるのは，

1）皮膚に必要な油性物質と水性物質を同時に，しか もそれぞれ単独の場合よりもはるか効果的に供給し得 て, 皮膚の柔軟性と湿潤性を保たせらる。

2) 使用感がすぐれ, しかも油相, 水相の種類, 混合 比, エマルションの型などを変えることによってかなり 任意に使用感を変えらる。

3）洗浄性にすぐれ，必要に忘じ製品を使用後洗い落 としやすい。

4）製品の外観が美しい。

などであるが，このほか顔料がはいったメーキャプ製品 の場合には基片としてェマルションを用いると顔料が沈 降しにくいといった利点もある。

しかし, エマルションは本質上油と水の混合系であり 不安定系であるので，これを化粧品といら商品に利用す
るには調製上種々の難点がある。第 1 亿商品であるため には，使用性や外観が一定期間不変でなければならな い。この一定期間は在庫期間, 商店の陣列期間のほかに 消費者の手に渡って消費され終るまでの期間を加算しな ければならないので, 商品の種類や販売経路によっても 異なるが，少なくとも $2 \sim 3$ 年ぐらいの安定性の保証が 必要である。しかもこの間, ショーウインドウの中や消 費者の手むとで光や熱（高温や低温）にさらされること を考慮しなければならない。第 2 亿化粧品は人間の皮膚 に対し連日, しかも長期的にわたり使用されるものであ り，乙かもし好品的な性格もあるので使用できる原料や 界面活性剤が限定され，皮膚に刺激を与えたり，不快な においや濃い色調をむっていてはならない。第 3 に化粧 品法使用效果や使用感が目的であるから, たとえエマル ションの安定性に不利な香料や薬剤や防腐鼡であっても 必要ならば添加しなければならないなどである。化粧品 にエマルションを用いた歴史は古く、コールドクリーム は Galen によって，すでに 2 世紀に作られたとのこと である。

戦後非イオン界面活性剤が発達するまでは, 化粧品用 エマルションの乳化剈としては陰イオン系のステアリン 酸セッケンやミッロウとホウ砂から得られるセロチン酸 セッケンなどがおもに用いられてきた。

$$
\begin{gathered}
\mathrm{C}_{25} \mathrm{H}_{51} \mathrm{COOH}+\mathrm{Na}_{2} \mathrm{~B}_{4} \mathrm{O}_{7} \rightleftarrows \\
\text { セロチン酸 }
\end{gathered}
$$

セッケンを乳化剂として用いる場合は脂肪酸を油相に 添加し, アルカカリを水相に添加して掠いて, 油相と水相 を混合する際に同時にセッケンを作り，そのセッケンに よって乳化するといらいわゆる“発生機法”がしばしば 用いられる。発生機法による方があらかじめ調製されて いるセッケンを用いるよりも乳化力が強いという報告1 むある。乳化剂としてセッケンを用いる長所は $\mathrm{O} / \mathrm{W} エ$ マルションの場合は乳化処理が容易であり，しかもかな り強力であって，大概の油を簡単俘乳化できることと， こうして生成したエマルションは安定化するとともに製 
品の構造粘性が増大するといらことである。

非イオン界面活性剤の場合は，活性剤の選定がむずか しく，良く適合した乳化剂を使用しないとエマルション が安定化しないとともに，エマルションに構造粘性を与 えるためには内相の比率を増加したり，外相の粘度を上 げたりしなければならない。しかし，内相の比率を上げ たりすると使用感が重くなりやすい。

非イオン界面活性剤が発達した現在でもバニシングク リームやバニシング系統の乳液比較的セッケン乳化が 多く用いられるのは，これらの製品がある程度の硬度を 持ちながら，しかもさっぱりした感触を要求されるから である。しかし，セッケン乳化にもいくつかの問題があ る。セッケンのみによる乳化では鉱物系の油を多く含ん だ $\mathrm{O} / \mathrm{W}$ エマルションや $\mathrm{W} / \mathrm{O}$ エマルションを安定化 するのはむずかしい。非イオン界面活性剤が導入される 以前は $\mathrm{W} / \mathrm{O}$ エマルションには金属セッケンや吸水性 ノリンなどが乳化剂として用いられてきたが，ほとんど 安定なものが得られなかった。またセッケン乳化による エマルションは硬度の温度依存性や経日変化が大きく, しかも製造条件（おもに冷却コウ配やかくはん条件）の 差異による特性のばらつきも大きい。

このような理由から化粧品のエマルションにも多くの 非イオン界面活性剤が使用されるようになってき た。非イオン界面活性剤を用いる利点は

1）良く適合した非イオン乳化剤を選定すると 長期にわたって安定なエマルションが得られ る。

2）中性または酸性のエマルションを作りう る。人間の皮膚は $\mathrm{pH} 5.3$ くらいの酸性であ るから，中性をたは酸性の製品を用いる場合 が多い。

3）アルカリ性で使用できない薬剤や酸性物質 を使用できる。

などである。

非イオン界面活性剤と陰イオン界面活性剤を併 用して両者の長所欠点を補い合う場合も多い。陽 イオン界面活性剤は殺菌効果もあっておもしろい が，実際にはにおいが悪く皮膚に対して刺激性の あるものがあって乳化剂としては化粧品にあまり 使用されていない。

非イオン界面活性剤としては，ポリオキシェチ レンのアルキルエーテル $\left(\mathrm{C}_{12} \sim \mathrm{C}_{18}, \mathrm{C}_{18: 1}\right)$, アル キルアリルェーテル（オクチルフェニルェーテル やノニルフェニルェーテルなど), アルキルエス テル，ソルビタンアルキルエステルを始め, 多価 アルコールと脂肪酸のエステル型, ポリオキシエ チレンとポリオキシプロピレンの縮合型など多く のものが用いられている。非イオン界面活性剤の
選択に対する指針としては HLB 法があるが，使用す る油と活性剤の化学構造上の親和性を考慮することも実 際上重要である。

化粧品の主原料の一つである流動パラフィンを用い化 学構造別に 106 種の非イオン界面活性剤を選び, そのお のおのに対して活性剤の使用量を $4 ， 8 ， 12 \%$, 油相比 を $30,50,70 \%$, 油相と水相の混合順序を油相を水相に 添加した場合, 水相を油相に添加した場合, 油相と水相 を同時に添加した場合の 3 水準として $\mathrm{L}_{9}\left(3^{4}\right)$ の実験計 画法により実験した結果 ${ }^{2}$ によると，ポリオキシエチレ ンのアルキルエーテル型, アルキルアリルエーテル型, アルキルエステル型活性剤などはエチレンオキシド数に よって乳化力が異なり, 安定なエマルション（分離度の 平均值 $\bar{y}=0$, 実験誤差 $\left.\hat{\sigma}_{e}=0\right)$ を得るためには最適エ チレンオキシド数をもつ活性剤を選定することが重要で あるが, ポリオキシエチレンのソルビタンアルキルエス テル型活性剤の場合はエチレンオキシド数によってあま り乳化力が異ならなかった。実験結果の一例を 図-1 に 示す。分離度は油相と水相に完全に分離したものを 20 , 分離しないものを 0 として評点をつけた。

またポリオキシエチレンのオレイルエーテルとステア リルエーテルを比較すると同じ HLB でもオレイルエー
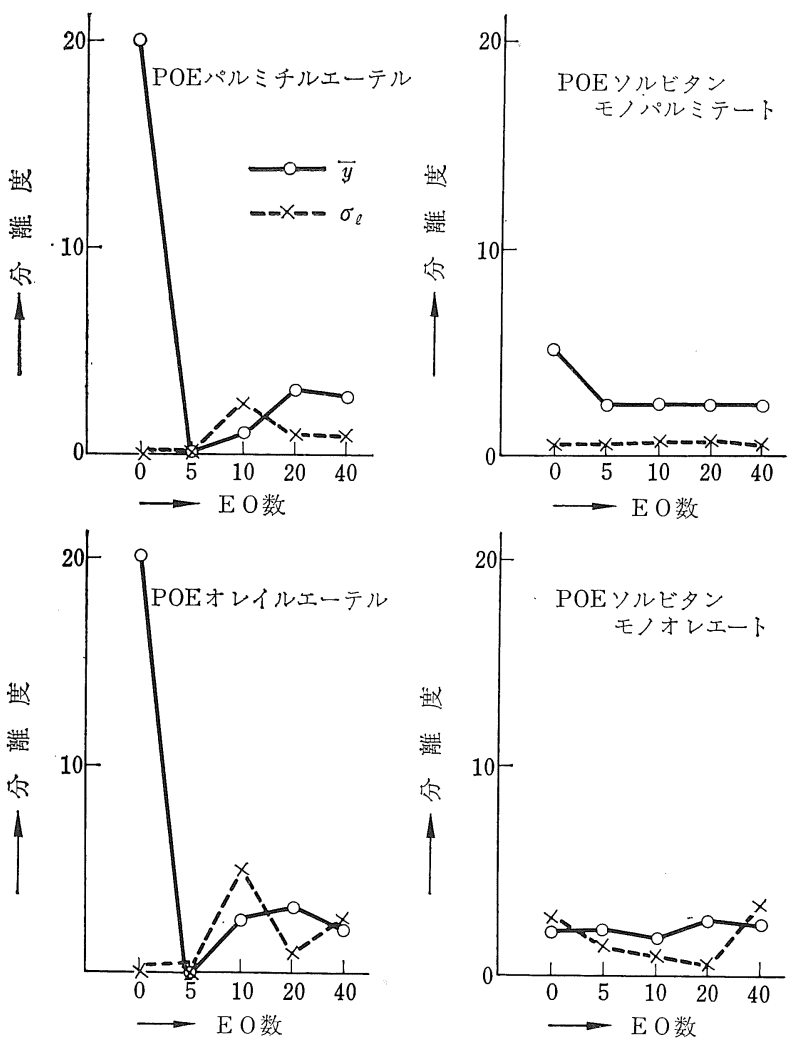

図-1 界面活性剂の $\mathrm{EO}$ 数とエマルションの分離度 $\left(37^{\circ} \mathrm{C}, 24 \mathrm{hr}\right.$ 放置後) 
表-1 POE オレイルエーテルとステアリルエーテルを 用いた場合の $\mathrm{W} / \mathrm{O}$ エマルションの出現数 $\left(\mathrm{L}_{9}\right.$ の実験計画法によって調整した 9 種のエマルシ ョン中の $\mathrm{W} / \mathrm{O}$ エマルションの数)

\begin{tabular}{|c|c|c|c|c|c|}
\hline EO 数 & 2 & 3 & 4 & 5 & 6 \\
\hline 活性剂 $\mathrm{HLB}^{*}$ & 4.9 & 6.6 & 7.9 & 9.0 & 9.9 \\
\hline POE オレイルエーテル & 6 & 9 & 6 & 3 & 0 \\
\hline POE ステアリルエーテル & 0 & 0 & 0 & 0 & 0 \\
\hline
\end{tabular}

*川上式により算出

テルの方がはるかに W/O エマルションを作りやすかっ た(表-1)。

乳化牏の使用量は油相と水相の種類によって異なるが 普通 2 8\%ぐらい用いられる。使用量が多いとエマル ションが安定化して, 少しぐらいの製造条件の変動では 影響されなくなるが，反面あまり多いと皮膚障害を起こ したり，逆にエマルションを不安定にすることがある。 しかし，ステアリン酸のモノグリセリドのような活性剤 は乳化剤としてよりも基剤の固型成分の一つとして用い られる場合があり，そのよらな場合にはかなり多量に使 用される。その他へアーリムーバーのように高度にアル カリ性の製品にはエステル型の乳化剤よりもエーテル型 の乳化剤, すなわちポリオキシエチレンアルキルエーテ ルなどの方が化学的に安定なので用いられる。

\section{$1 \cdot 1$ クリーム}

化粧品のクリームは使用目的によって多種類に分かれ るが大別すると親水性クリーム，中性クリーム，親油性 クリームの 3 種類になる。

親水性クリームはバニシングクリームやひげそり後に 用いるアフターシェービングクリームなどである。この クリームの特徴は使用感がさっぱりしていることであ り，バニシングクリームは皮膚に整布して伸ばすとバニ シュ (vanish)，すなわち消失するようみえるのでこの 名称がつけられたものといわれる。油相はステアリン酸 のよらな脂肪酸を主体として少量の高級アルコール，油 脂が添加され，水相にはグリセリン，プロピレングリコ ールなどが添加される。さっぱりとした使用感を目的と するので乳化はおもに発生機法のセッケン乳化による場 合が多い。すなわち水相に水酸化カリウムや水酸化ナト リウムを添加し, 油相との混合時, 油相中のステアリン 酸をケン化し，生成した酸性セッケンによって乳化を行 なわせる。乳化は比較的容易に行なわれるが，水相と油 相の混合速度があまり速いとセッケンのかたまりができ てクリームが均一化しなかったり，冷却速度などがばら つくと製品特性が影響を受けやすいなどの欠点がある。 これも親水性の非イオン乳化㓮の導入や乳化機の発達に よりかなり改良されてきた。非イオン乳化㓮のみでも親 水性クリームは作れるが, 使用感が重くなりやすいの
で，セッケン乳化と併用される場合が多い。

この系統のクリームは $\mathrm{O} / \mathrm{W}$ エマルションに分類され ているが, 油相がおもにステアリン酸のような固型成分 からなるので䩦密にはサスペンションの性格も含まれ る。以前は親水性クリームがクリームの主軸であった が, 戦後化粧品全般の流行が油性化粧となり多くのバニ シングクリーム愛好者も中性クリームに移行した。しか し，特にさっぱりした感触を要求されるアフターシェー ビングクリームや男子用クリームには現在でもこの系統 のクリームが多い。

\section{処方例 1}

\begin{tabular}{|c|c|}
\hline ステアリン酸 & $17.0 \%$ \\
\hline セチルアルコール & 1.0 \\
\hline グリセリンモノステアレート & 2.0 \\
\hline グリセリン & 6.0 \\
\hline \multicolumn{2}{|l|}{ ポリオキシェチレン } \\
\hline ソルビタンモノステアレート & 1.0 \\
\hline カセイカリ & 0.5 \\
\hline 精製水 & 72.0 \\
\hline 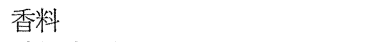 & 0.5 \\
\hline 酸化防止剂および防腐剤 & 適量 \\
\hline \multicolumn{2}{|l|}{ 方例 2} \\
\hline ステアリン酸 & 16.0 \\
\hline $\begin{array}{l}\text { ソルビタンモノステアレート } \\
\text { ポリオキシエチレン }\end{array}$ & 2.0 \\
\hline ソルビタンモノステアレート & 1.5 \\
\hline プロピレングリコール & 10.0 \\
\hline 精製水 & 70.0 \\
\hline 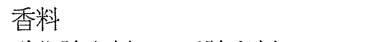 & 0.5 \\
\hline 酸化防止剂および防腐剂 & 適量 \\
\hline
\end{tabular}

中性クリームは親油性クリームと親水性クリームの中 間的な使用感をもつクリームという意味である。油相が 脂肪族アルコール（ステアリルアルコールやセチルアル コール）を中心として作られている以外は親水性クリー ムと同じである。ただ使用感がバニシングクリームより 油っぽく、コールドクリームよりさっぱりしているので し好的に人気を呼び, 販売量も増化しつつある。使用感 がマイルドなのでベビークリームを始め，アストリンゼ ントクリームやエモリエントクリーム (emollient) など 各種の薬用クリームのベースに用いられる。

\section{処方例 3}

$\begin{array}{lr}\text { ステアリルアルコール } & 8.0 \% \\ \text { ステアリン酸 } & 4.0 \\ \text { ミッロウ } & 3.0 \\ \text { ラノリン } & 3.0 \\ \text { グリセリンモノステアレート } & 2.0 \\ \text { プロピレングリコール } & 10.0 \\ \text { 水酸化カリウム } & 0.2 \\ \text { 精製水 } & 69.3 \\ \text { 香料 } & 0.5 \\ \text { 酸化防止杪拉よび防腐剂 } & \text { 適量 }\end{array}$

親油性クリームはコールドクリームが代表的なもの で，一般に油っぽい感じで皮膚に塗布すると透明感があ る。皮膚に油分を供給し, なめらかにするのが目的であ るから多量の油相を含み, 油相としてはミツロウ, 固形 
パラフィン，ワセリン，ラノリン，流動パラフィンなど が多く用いられる。

皮膚のよごれや化粧を落とすクレンジングクリームや 皮膚のマッサージの際用いるマッサージクリームや皮膚 に栄養を与える栄養クリームなどがこのタイプに属す る。O/W タイプと W/O タイプがあり，O/W タイプ の乳化には油相にミツロウ, 水相にホウ砂を添加して両 相の混合時ミツロウ中のセロチン酸をホウ砂でケン化 し，生じたセロチン酸ナトリウムで乳化するといら発生 機法が用いられてきた。この方法は非常に簡便である が，この系統のクリームのように油相の多い（40７0\% くらい) 系の場合にはセッケンのみで安定なエマルショ ンを作るのは困難であった。近年非イオン乳化剤の導入 と乳化機の発達により安定なものが比較的容易に製造さ れるよらになり，現在の油性化粧の流行に伴いクリーム 界の花形として生産量も多い。W/O 型クリームは金属 セッケン, 粉末, ミッロウ, ホウ砂, 吸水性ラノリンな どを用いて作られてきたが，O/W 型クリーム以上に乳 化がむずかしいのでほとんど完全な製品はなかった。こ れもソルビタンセスキオレート (Arlacel C) を始め, 多くの非イオン界面活性剤の導大により良い製品が数多 くできるよらになった。

$\mathrm{W} / \mathrm{O}$ 型クリームも $\mathrm{O} / \mathrm{W}$ 型の親油性クリーム同様ク レンジングクリーム，マッサージクリーム，栄養クリー ムとして用いられるが，O/W 型クリームよりも油性の 強い製品ができる。

\begin{tabular}{|c|c|}
\hline ミツロウ & $10.0 \%$ \\
\hline 固型パラフィン & 5.0 \\
\hline ワセリン & 6.0 \\
\hline 流動パラフィン & 50.0 \\
\hline & ポリオキシエチレン \\
\hline ソルビタンモノオレート & 2.0 \\
\hline 精製水 & 24.3 \\
\hline ホウ砂 & 0.2 \\
\hline 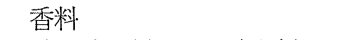 & 0.5 \\
\hline 酸化防止剤叔よび防腐郕 & 適量 \\
\hline \multicolumn{2}{|l|}{ 処方例 5 (W/O) } \\
\hline セレシン & $8.0 \%$ \\
\hline 固型パラフィン & 5.0 \\
\hline 流動パラフィン & 40.0 \\
\hline オリブ油 & 10.0 \\
\hline ワセリン & 12.0 \\
\hline 脱水ラノリン & 5.0 \\
\hline ソルビタンセスキオレート & 4.0 \\
\hline 精製水 & 15.5 \\
\hline 香 料 & 0.5 \\
\hline 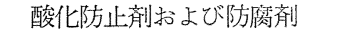 & 適量 \\
\hline
\end{tabular}

\section{$1 \cdot 2$ 乳 液}

乳液はクリームの液状のものであるから, その原理, 区分はクリームとまったく同様である。しかし，クリー ムに比較して粘度が低いので安定性が悪く, 粒子の浮上
や沈降を起こしやすい。

O/W 型の乳液の場合には保護コロイド性のある水溶 性の高分子物質を添加して安定化する場合もあるが，使 用目的上から高分子物質を添加できない場合や，また添 加しても効果のないW/O エマルションの場合にはよく 適合した乳化剂を選び，粒子がある程度細かく界面膜の 強いエマルションを作らなければならない。乳化剤が今 日ほど発達するまでは油分の少ないバニシング系統の乳 液のみであったが，最近はかなり油相の多いO/W 型乳 液やさらには W/O 型乳液まで作られるようになった。 W/O 型乳液は安定化がきわめてむずかしい。

乳液はクリームに比較して使用しやすく膚に均一に広 く薄く伸ばすことができて使用感が良いので最近需要量 がかなり増加してきた。

\begin{tabular}{|c|c|}
\hline 処方例 6 (O/W) & \\
\hline ステアリン酸 & $8.0 \%$ \\
\hline セチルアルコール & 0.5 \\
\hline ラノリン & 0.5 \\
\hline オレイルアルコール & 2.0 \\
\hline $\begin{array}{l}\text { ソルビタンセスキオレート } \\
\text { ポリオキシエチレン }\end{array}$ & 0.5 \\
\hline ソルビタンモノオレート & 2.5 \\
\hline 精製水 & 85.5 \\
\hline 香料 & 0.5 \\
\hline 酸化防止凪および防腐郕 & 適量 \\
\hline 処方例 7 (W/O) & \\
\hline ワセリン & $8.0 \%$ \\
\hline 流動パラフィン & 52.7 \\
\hline ラノリン & 3.0 \\
\hline ミツロウ & 2.0 \\
\hline ステアリン酸要鉛 & 0.5 \\
\hline ソルビタンセスキオレート & 3.0 \\
\hline ポリオキシェチレン & \\
\hline ソルビタンモノラウレート & 0.3 \\
\hline 精製水 & 30.0 \\
\hline 香料 & 0.5 \\
\hline 酸化防止剂㧍よび防腐剤 & 適量 \\
\hline
\end{tabular}

\section{2 可溶化剂として}

界面活性剂による可溶化現象は化粧品工業の場合，お もに化粧水の製造に利用されている。化粧水は透明液状 の化粧品で皮膚に対し柔軟性や湿潤性や収レン性を与光 ることを目的とする。酸性, アルカリ性, 中性のものが あり, おもな成分は柔軟剤, 湿潤剤, 収レン剤, アルコ 一ル類, 少量の油類, 香料, 薬剤などである。

乳液に比べ油類が少ないので使用感はさっぱりしてい て，使用分野も広い。ほとんどの化粧水にはアルコール が含まれているが，20〜30\% 以下なので水に対して不 溶性の香料や油類や薬剤を溶解できず，したがって可溶 化剂としての界面活性剤が必要となる。以前は香料など をアルコールとともに添加し，白濁させたあとにタルク や炭酸マグネシウムを少量加え，かくはん冷却して不溶 の香料を粉末に吸着させロ過して透明化していた。した 
がって，工程的に時間がかかるのみならず，香料はかな りの量を添加しても実際に製品に溶解するのはきわめて 少量でその大部分は口過して捨て去るといらむだが行な われていた。またこの方法では香料は飽和状態で溶解し ているので, 温度変化や長期の経日によって香料が再析 出しやすい傾向があった。

界面活性剂による可溶化現象の利用により少量の香料 で強く賦香できるようになったのみならず，油性物質や 油溶性薬剤（油溶性ビタミン類など）を添加することも 可能になり製品の安定性も向上した。ただ可溶化剂を用 いた場合の注意点は

1）可溶化剤を用いない場合とにおいだちや薬剤の作 用性が変わる可能性があるのでその点を注意しなけ ればならない。

2）化粧水の場合はとくに色やにおいが重要なので, 可溶化剤が経日により染料や香料を変化させるもの であってはならない。

3）化粧水は不揮発性成分が少ないので可溶化剤が皮 膚刺激の原因になりやすい。

4）一般に化粧水はさっぱりした使用感を特徵とする ので，可溶化剤を多く用いるとべたつきの原因にな りやすい。

などであろら。

最近, 可溶化現象は化粧水以外に男性用整髮料に応用 されるよらになった。以前は男性用整髮料としては植物 性または鉱物性ポマードが主軸であった。植物性や鉱物 性のポマードは単に植物性または鉱物性オイルをワック ス類と混合し，賦香したものであったが，新整髪料は水 中に多量のオイルやワックス類を透明に溶解したもので ある。頭髪はタンパク質の一種であるケラチンであり， ポリペプチドからできている。正常な状態では屈曲した $\alpha$ 型の配列をしているが，まっすぐに伸ばすと $\beta$ 型の配 列となる。 $\alpha$ 型から $\beta$ 型に分子内転移を起こすためには ，頭髮に湿気を含んでいることが必要であって，湿気が ない場合には頭髪を伸ばすことも縮めることもできな い。したがって頭髮をぬらしてからカールし，そのまま の状態で乾燥させたならば原型に復しがたくなり，これ をウォーターウェーブといら。以前のポマードは単にオ イルとワックスの粘りで整髪するのみであったが，新整 髪料の場合は水が含まれているのでウォーターウェーブ 的効果による整髮性が付与されている。使用感がさっぱ りしているのが特徴であり, 同時に洗髮性もはるかにす ぐれている。

以上は水中に油を可溶化した例であるが，その他油中 に水を可溶化した例もある。たとえば先に述べた従来の ポマードやへヤーオイルに少量の水を添加して整髪性や 洗髪性を良くしたものや，口紅はオイルとワックスにレ 一キや染料を添加したものであるが，口紅に少量の水や

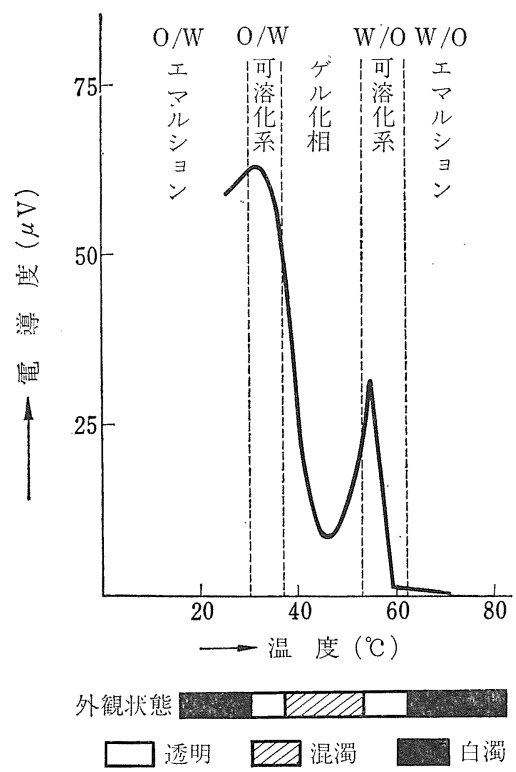

図-2 流動パラフィンー水-POE (7 mol) オレイルエー テル系の 電導度と外観状態の温度変化 (界面活 性剂量 $20 \%$, 流動パラフィン: 水=6:4)

湿潤剂を添加して唇に対する湿潤性を増したものなどが ある。ただ W/O 型の可溶化は $\mathrm{O} / \mathrm{W}$ 型に比較して安定 性が悪い場合が多い。一般に可溶化系の場合, O/W か ら W/O への移行過程において中間に明りょらなゲル化 相が現われる(図-2)。

化粧品では，これらの諸段階の可溶化現象が製品に利 用され得るが，問題は温度変化や原料のロットのばらつ きなどによって系の透明性を始め，諸性質が影響を受け やすい点であろう。

\section{$2 \cdot 1$ 化粧水}

化粧水の場合，おもに可溶化の対象となるのは香料で ある。香料は単品の天然香料や合成香料を調合したもの であるが，単品香料のおもなものとしてはゲラニオー ル，リナロール，シトロネロール，テルピネオール，フ ェニルェチルアルコール，シトロネラール，シトラー ル，オキシシトロネラール，ベンジルアセテート，ゲラ ニルアセテート，リナリルアセテート，ヨノン，オイゲ ノール，クマリン，ムスクケトンなどがある。一般に極 性基をもち，アルコールに溶けやすく（ムスクケトンは 溶けにくいが) その使用量も $0.5 \%$ 以下の場合が多いの で可溶化はそれほど難しくない。ただ透明な製品が多い ので，市場において白濁したり，沈殿が生じたりすると 問題になる。したがって，可溶化剤の使用量も必要最少 量よりもいくらか多くしておかなければならない。ただ あまり多いと先に述べたよらににおいや使用感が悪くな ったり皮膚刺激を起こしたりすることがある。

可溶化剂としてはポリオキシエチレンのアルキルエー 
テル型 $\left(\mathrm{C}_{12} \sim \mathrm{C}_{18}, \mathrm{C}_{18: 1}\right)$, アルキルエステル型, ソルビ タンアルキルエステル型をはじめ, 多くの親水性界面活 性剂が用いられる。

\begin{tabular}{|c|c|}
\hline プロピレングリコール & $4.0 \%$ \\
\hline エチルアルコール & 20.0 \\
\hline トリエタノールアミン & 0.2 \\
\hline 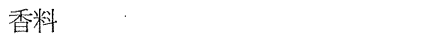 & 0.2 \\
\hline ポリオキシエチンンラウリルエーテル & 1.0 \\
\hline 精製水 & 74.6 \\
\hline 染料 & 適量 \\
\hline 酸化防止㧩および防腐剤 & 適量 \\
\hline
\end{tabular}

アルカリ性化粧水は皮膚に柔軟性を与えるとともに， 皮膚に付着したよごれや皮膚から分泌された脂肪分をと り除く目的に用いられる。アルカリが用いられているの で可溶化剂はエーテルタイプのものが適している。

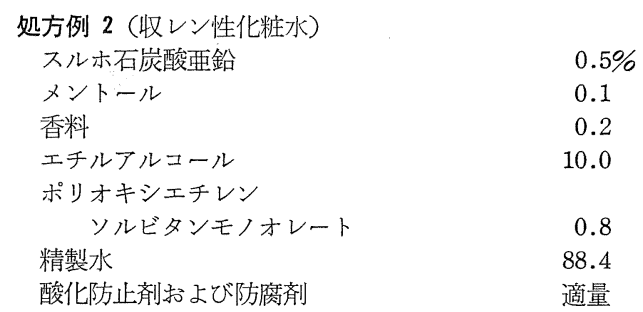

いわゆる“アストリンゼントローション”と呼ばれる もので皮膚に対して収レン性を示す化粧水である。皮膚 の毛孔をひきしめ過剰な油分をおさえることを目的とす る。アストリンゼントローションはさっぱりした化粧水 だからべたつかないように可溶化剤の量をできるだけ少 なくする必要がある。

\section{$2 \cdot 2$ ゲル状透明整髪料}

先に述べたように新男子用整髪料は油と水と界面活性 剂の三成分系からなる透明ゲル状製品であって，従来の ポマードより使用感がさっぱりしていて洗髪性もすぐれ ている。おもに可溶化の対象となる油はオリブ油, ヒマ シ油，流動パラフィン，ラノリン誘導体などであり，そ れにいくらかのワックス類がはいる。この製品の場合は 化粧水よりはるかに多量の油が透明に溶解しているので 製造条件のばらつきや原料ロットのばらつきにより製品 の安定性が变化しやすい。

\section{処方例 3}

$\begin{array}{lc}\text { 流動パラフィン } & 26.0 \% \\ \text { ウールワックスアルコール } & 2.0 \\ \text { ポリオキシェチレンオレイルエーテル } & 20.0 \\ \text { グリセリン } & 10.0 \\ \text { 香料 } & 0.3 \\ \text { 精製水 } & 41.7 \\ \text { 酸化防止剂抒よび防腐剂 } & \text { 適量 }\end{array}$

\section{3 分散剂として}

化粧品，とくにメーキャップ製品には各種の顔料を用 いたものが多いので，その分散性や分散媒に対する“ぬ
れ”ということが重要な問題になる。化粧品に顔料を用 いるおもな目的は

1）皮膚の色を魅力的に変える。以前はおしろいによ って白く装うのが括もであったが，最近は自分の皮 膚の色と同じか，やや濃いめに装らことが多くなっ た。

3）皮膚が分泌物のために油ぎって光るのを防ぎなめ らかなビロードのような感じを与える。

4) シミ，ソバカス，シワのような皮膚の欠陥をかく す。

などであるが，このほかサンスクリーンのような日焼け 止めクリームの場合は紫外線しゃ断のために白色顔料を 添加する場合もある。

これらの目的のために白色顔料としては酸化チタン， 酸化亜鉛，硫酸バリウム，カオリン，炭酸マグネシウ ム，炭酸カルシウム，タルク，水酸化アルミニウム，金 属セッケンなどが用いられ，着色顔料としては酸化鉄， ウルトラマリン，カーボンブラックや各種の有機レーキ が用いられる。最近はまたパール入りの化粧品（口紅， アイシャドウ，ネールエナメルなど）が愛好されるよう になったが，これらのパール甋としては魚リンハクやオ キシ塩化ビスマスなどが用いられる。

粉末は粉おしろいのよらに粉末単独で用いられる場合 もあるが多くの場合，水や油や有機溶媒などに分散され て用いられる。分散媒の差異によって粉末分散系の化粧 品を分類すると 表-2 のようになる。

表-2 粉末分散系の化粧品

\begin{tabular}{|c|c|c|c|}
\hline 系 & $\begin{array}{c}\text { 粉末量 } \\
(\%)\end{array}$ & 分 散 媒 & 製 品 名 \\
\hline 粉末～水䎹 & $10 \sim 20$ & $\begin{array}{l}\text { グリセリン，水な } \\
\text { ど }\end{array}$ & 水白粉 \\
\hline \multirow{2}{*}{$\begin{array}{l}\text { 粉末ーオイル } \\
\text { ワックス采 }\end{array}$} & $5 \sim 50$ & $\begin{array}{l}\text { 流動パラフィン, } \\
\text { ママシ油, ラノリ } \\
\text { ソミミシャなど }\end{array}$ & $\begin{array}{l}\text { 口紅, ほ小紅, フ } \\
\text { フシデーショソス } \\
\text { チック, アイシャ } \\
\text { ドウ }\end{array}$ \\
\hline & $80 \sim 95$ & 上 & 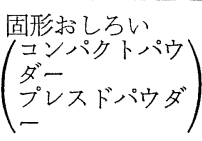 \\
\hline \begin{tabular}{r|} 
粉末-有機 \\
溶媒系
\end{tabular} & $1 \sim 2$ & $\begin{array}{l}\text { アルコール, 酶酸 } \\
\text { エチル,トルエン, } \\
\text { =トロセルロース } \\
\text { など }\end{array}$ & ネールエナメル \\
\hline $\begin{array}{r}\text { 粉末ーエマル } \\
\text { ショ采 }\end{array}$ & $5 \sim 40$ & $\begin{array}{l}\text { 流動パラフィン, } \\
\text { ワセリン, 固型パ } \\
\text { ラフィンなどの } \\
\text { O/WおよびW/O } \\
\text { エマルション }\end{array}$ & $\begin{array}{l}\text { フォンデーション } \\
\text { クリーム, フォン } \\
\text { デーションローシ } \\
\text { ョソ, 日焼け止め } \\
\text { クリーム }\end{array}$ \\
\hline
\end{tabular}

これら粉末分散系の化粧品では分散媒に対する粉末の ぬれや分散性の良否が重要な問題になってくる。粉末を 含む乳液やネールエナメルの場合，分散が悪いと顔料が 沈降したり色分かれを起こす。口紅やフェースチックの 
場合，“ぬれ”や分散が悪いと色調が局部的に異なり， いわゆる“らき”を生じたり，“むらづき”を起したり する。また製品の安定性も劣化し，“発粉”（製品中の 1 部のオイルやワックスが分離し，製品表面上に粉状に 析出する現象）したり，経日により硬化したりする。

粉末の分散を良くするためには一般に

1）機械的方法によって粉末を微粉化する。

2）粉末の沈降を防ぐような良い分散媒を用いる。

3）粉末の表面に荷電を与える。

4) 粉末の表面を親媒性にする。

などの方法が考えられるが，これらのらち，分散剤とし ての界面活性剤の機能に期待するのはおもに 3)，4）の 効果である。すなわち，界面活性剂は固-液界面に吸着 して界面エネルギーを低下させ，粉末の表面を親媒性に するほか，イオン性の界面活性剂はら電位を増加させ, 静電的斥力の増大によって接着を阻止する。化粧品の場 合，表-2 に示したように分散系は大別すると粉末一水系 と粉末一非水系になり，粉末は 親水性の無機顔料と親油 性の有機顔料になる。粉末一水系の場合，分散性に影響 を及ぼす重要な因子は $\zeta$ 電位であり，無機顔料を分散 させる場合など $\zeta$ 電位を高めるために各種のイオン性 活性剤をはじめ，アルミニウムイオンやリン酸イオン (ヘキサメタリン酸ナトリウム) などが用いられる。粉 末一非水系でもら電位は分散性にある程度の影響を及ぼ すが゙3，この場合は疎媒性の粉末表面をいかに親媒性に し，分散媒にぬれやすくするかということが実際上最も 重要な問題となる。界面活性剤により粉末表面を親媒化 し，ぬれや分散性を向上するためには親油性粉末を水系 に用いる場合には親水性の界面活性剂が，親水性粉末を 非水系に用いる場合には親油性の界面活性剂が用いられ る。

界面活性剤としてはステアリン酸セッケンや各種の金 属セッケン, アルキルアミン，ジアルキルスルホサクシ ネートラノリン誘導体, ポリオキシエチレンのアルキル エーテル, アルキルェステル, ソルビタンアルキルエス テルなど多くの種類が用いられる。界面活性剤の選定は 先に述べたように粉末表面と分散媒の極性, 非極性のバ ランス (HLB) からある程度の推測は立てられるが，実 際の場合に使用される分散媒はたとえオイルであっても ある程度の極性をもったオイルが多く, 粉末表面も表面 コーチングされていたり不純物を含んでいるので，単純 に割り切れない場合が多い。また分散性を考える場合に は粉末表面に対する界面活性剤の化学構造的な親和性や 吸着力も重要である。

表-3 は市販のルチル 型の酸化チタンを 硝酸アルミニ ウム水溶液 $(0.005 \mathrm{~mol} / l)$ の中に分散させ, 粉末表面に $\mathrm{Al}^{3+}$ イオンを吸着させたのち, 各種の陰イオン界面活 性剂を添加し, 粉末の表面を踈水化したものを, 比較的
表-3 活性剂処理酸化チタンの分散性

\begin{tabular}{|c|c|c|c|c|c|c|c|c|c|c|c|c|c|}
\hline $\begin{array}{l}\text { 処理活性剂 } \\
\text { 分散媒（粘度 } \mathrm{cP} \text { ) }\end{array}$ & Nil & & & & & & & & & & & & \\
\hline $\begin{array}{l}\text { エチルアセテ } \\
\text {-ト }\end{array}$ & 1 & 0 & 3 & 0 & 6 & 0 & & & 4 & 3 & 6 & 6 & 0 \\
\hline 流動パラフィン(11.2) & 1 & 2 & 2 & 2 & 2 & 2 & 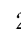 & & 2 & 2 & 7 & 7 & 2 \\
\hline スクワラン (20.5) & 3 & 3 & 3 & 3 & 5 & 3 & $\tau$ & & 3 & 3 & 7 & 7 & 3 \\
\hline $\begin{array}{l}\text { イソプロピル } \\
\text { ミリステート }\end{array}(<10)$ & 3 & 1 & 6 & 7 & 3 & 3 & 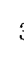 & & 7 & 3 & 7 & 7 & 1 \\
\hline $\begin{array}{l}\text { オレイルオレ (17.2) } \\
\text { エート }\end{array}$ & 5 & 3 & 4 & 4 & 5 & 5 & 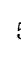 & & 4 & 3 & 7 & 7 & 7 \\
\hline オリブ 油 (47.4) & 6 & 5 & 5 & 0 & 6 & 0 & & & 5 & & 7 & 7 & 7 \\
\hline $\begin{array}{l}\text { 2-オクチル } \\
\text { ドデカノール }\end{array}$ & 6 & 3 & 3 & 3 & 7 & 3 & & & 7 & 6 & 7 & 7 & 6 \\
\hline $\begin{array}{l}\text { オレイルアル } \\
\text { בール }\end{array}$ & 6 & 6 & 7 & 7 & 7 & 6 & & & 7 & 6 & 7 & 7 & 7 \\
\hline $\begin{array}{ll}\text { ヘキサデシル } & \text { (37.8) } \\
\text { アルコール } & \end{array}$ & 3 & 3 & 5 & 3 & 7 & 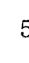 & & & 7 & 6 & 7 & 7 & 1 \\
\hline $\begin{array}{c}\text { メチルリシノ } \\
\text { レート }\end{array}$ & 5 & 4 & 6 & U & 6 & 6 & & & 7 & 5 & 7 & 7 & 5 \\
\hline オレイン酸 (22.1) & 7 & 7 & 7 & 7 & 7 & & & & 7 & 7 & 7 & 7 & 7 \\
\hline カスタ一油 (461.8) & 7 & 5 & 7 & 5 & 7 & 6 & & & 7 & 5 & 7 & 7 & 4 \\
\hline $\begin{array}{l}\text { イソプロピル } \\
\text { アルコール }\end{array}$ & 6 & 6 & 6 & $\gamma$ & 7 & $\gamma$ & & & 7 & 7 & 7 & 7 & 0 \\
\hline $\begin{array}{l}\text { テトラヒドロ } \\
\text { フルフリル } \\
\text { フルコール }\end{array}$ & 7 & 1 & 6 & 7 & 7 & 7 & & & 7 & 7 & 7 & 7 & 1 \\
\hline $\begin{array}{ll}\text { プロピレン } \\
\text { グリコール }\end{array}$ & 7 & 3 & 6 & 5 & 6 & $\epsilon$ & & D & 6 & 7 & 6 & 6 & 5 \\
\hline
\end{tabular}

$\mathrm{A}_{1}$ 硫酸化ヒマシ油

$\mathrm{A}_{2}$ 第二アルコール硫酸ナトリウム塩(チポールタイプ)

$\mathrm{A}_{3}$ ナトリウムモノグリセリルラウリルサルフェート

$\mathrm{A}_{4}$ ナトリウムドデシルベンゼンスルホネート

$\mathrm{A}_{5}$ ナトリウムラウリルサルフェート

$\mathrm{A}_{6}$ ナトリウムジラウリルホスフェート

$\mathrm{A}_{7}$ スルホンアミド(イゲポンTタイプ)

$\mathrm{A}_{8}$ ナトリウムオクチルフェノールエーテルサルフェート

$\mathrm{A}_{9}$ ナトリウムジオクチルスルホサクシネート

$\mathrm{A}_{10}$ ナトリウムジェチルヘキシルスルホサクシネート

C 第四アンモニウム塩

化粧品によく用いられる分散媒 (有機溶媒とオイル) 中 に分散させ，その分散度を調べた結果である。

比較のために 1 種の陽イオン界面活性剤も用いた。こ の場合は酸化チタンをへキサメタリン酸ナトリウム水溶 液 $(0.001 \mathrm{~mol} / l)$ で処理後陽イオン界面活性剤を添加し た。表中の数字 $(0 \sim 7)$ は分散度を示し, 数字が大きい ほど粉末の沈降が遅く，したがって分散性が良いことを 示す ${ }^{4)}$ 。表-3 に示されるよらに分散性は粉末を処理する 活性剤の種類と分散媒の種類によって影響される。分散 剂としては，ナトリウムドデシルスルホサクシネート $\left(\mathrm{A}_{9}\right)$ やナトリウムジェチルヘキシルスルホサクシネー 卜 $\left(\mathrm{A}_{10}\right)$ が最も効果的である。これはスルホサクシネ 一トタイプの基がこのような系の分散性にとくに有利で あるといら機能的特徵を持つことを推測させる。ただ し，化粧品の場合はいかに分散性を向上させる界面活性 剤であっても，においが悪かったり刺激性があったら使 用できないのは当然であり，また界面活性剤によっては 
レーキをブリードさせたり，染料を変色させるものがあ るので注意しなければならない。

以下に二，三の粉末系化粧品の例をあげる。

(1) 固型おしろい(コンパクト・パウダー)

粉おしろいを携帯に便利にし，また使用時に粉が飛散 しないように粉末を固めて容器に入れたいわゆるコンパ クトと称するものである。原料は粉おしろいとほとんど 変わらないが，少量の油性物質と結合剂と界面活性剂が 添加されている。この製品の場合は界面活性剤は多量の 粉末を少量の油性物質でぬらす目的で用いられる。

$\begin{array}{lc}\text { 処方例 } & \\ \text { タルク } & 52.9 \% \\ \text { カオリン } & 15.0 \\ \text { 酸化チタン } & 7.0 \\ \text { ステアリン酸互鋁 } & 5.0 \\ \text { ソルビット } & 4.1 \\ \text { プロピレングリコール } & 2.4 \\ \text { ソルビタンセスキオレート } & 9.7 \\ \text { ラノリンまたは鉱物油 } & 2.4 \\ \text { 香料 } & 1.5 \\ \text { 色素 } & \text { 適量 }\end{array}$

(2) 練紅

練紅は比較的少量のレーキをオイルワックス中に分散 させたものであるが，レーキのぬれや分散が悪いと成型 の際，色じまができたり経日により発粉，発汗を起こす ので界面活性剤を添加することがある。この場合界面活 性剂がレーキの色調を変化させないことが重要である。

$\begin{array}{lc}\text { 処方例 } & \\ \text { セレシン } & 15.0 \% \\ \text { ワセリン } & 40.0 \\ \text { イソプロピルミリステート } & 5.0 \\ \text { レーキ } & 10.0 \\ \text { 流動パラフィン } & 27.0 \\ \text { ソルビタンモノラウレート } & 2.0 \\ \text { 香料 } & 1.0\end{array}$

(3) ファンデーションクリーム

これは乳化性クリームに粉末着色料を配合したもので ある。乳化系と分散系の混合系であるから, 製品の安定 性やレオロジカルな性質が複雑な挙動を示すことがあ る。この場合も粉末の分散性が製品の外観や安定性に及 ぼす影響は大きい。

$\begin{array}{lc}\text { 処方例 } & \\ \text { 流動パラフィン } & 26.5 \% \\ \text { ラノリン } & 10.0 \\ \text { 固形パラフィン } & 5.0 \\ \text { ソルビタンセスキオレエート } & 4.5 \\ \text { ポリオキシエチレンソルビタン } & \\ \quad \text { モノオレート } & 0.5 \\ \text { 粉末着色料 } & 35.8 \\ \text { 精製水 } & 18.0 \\ \text { 香料 } & 0.5 \\ \text { 酸化防止剤および防腐片 } & \text { 適量 }\end{array}$

\section{4 ๘ $の$ 他}

その他界面活性剤は化粧品工業において洗浄剤, 起木 ウ剂，浸透剤，湿潤剤などとして広く用いられている。 以下に実際の製品例を中心としてその使用状況を略述す る。

$4 \cdot 1$ ポマード, ヘアーオイル

ポマードやへアーオイルにはヒマシ油や木ロウのよう な植物性の油やワックスを主成分としたものと, 流動パ ラフィンやワセリンのような鉱物性の油やワックスを主 成分としたものとがある。鉱物性のポマードやへアーオ イルは植物性のものより原料臭が少なく，化学的に安定 なので賦香が有利であり，良いに拉いの製品が作られる が, 反面洗浄性と整髪性が劣る。したがって, 日本では おもに植物性の製品が愛好されていたが, 最近, 界面活 性剂を添加することによりかなり洗髪性のすぐれた鉱物 性の製品が作られるようになった。

\section{$4 \cdot 2$ コールドウェーブローション}

コールドウェーブローションはチオグリコール酸塩の 作用により毛髪のケラチン分子間のイオウ橋を切断し， 毛髪に好みのカールを与える製品である。第 1 剤はチ才 グリコール酸塩やアンモニアや少量の油, 界面活性剤か らなり毛髪の力橋の切断を目的とし, 第 2 凨は臭素酸力 リウムや過ホウ酸ナトリウムのよらな酸化㓮からなり， 第 1 剂で処理後, チオグリコール酸の作用を停止させる ことを目的とする。この製品の場合, 界面活性剤は第 1 剤中の油を乳化または可溶化することと, 薬液の毛髪に 対する浸透性を増加する目的で使用される。

\section{$4 \cdot 3$ 染毛剂}

染毛剂のらちで現在最も広く使用されているのは酸化 染毛剂である。この染毛剂の染色機構は染料が単に毛髪 表面を被覆するのではなく，染料中間体である酸化染料 が毛髪の内部層に浸透し, 酸化されて不溶性色素となり 沈着するものである。したがって, 染毛剤は酸化染料の 含有された染毛基剤と適当な酸化剂とよりなる。染色後 は未反応の基剤, および過剩の酸化剤を洗い落とすこと が必要である。染毛基剤は酸化染料（o-, p-ベンゼンジ アミン,o-, $p$-アミノフェノールなど), アルカリ剂, ア ルコール類, 界面活性剤などよりなり, 酸化剤には過酸 化水素水などが使用される。この製品の場合，界面活性 剤は酸化染料の均一な浸透を助長させる目的と染料溶液 の増粘効果と染毛後の洗浄を 促進する目的で使用され る。

\section{$4 \cdot 4$ シェービングクリーム}

シェービングクリームにはラザリングタイプのものと ブラッシュレスタイプのものとがある。ラザリングタイ プはアワ立ちの多いシェービングクリームであり，ブラ ツシュレスタイプはアワ立ちのほとんどないバニシング 
タイプのシェービングクリームである。ラザリングクリ 一ムは 40〜50\% の脂肪酸セッケンを含むものが多い が,この製品の場合, 起ホウ性の向上と基剤の安定化の ために界面活性剂を併用することがある。

$4 \cdot 5$ エモリエントクリーム (湿㵎, 柔軟クリーム) 皮膚に湿潤柔軟性 (emollience) を与えることを目的 としたクリームである。湿潤柔軟刻としてはグリセリン やプロピレングリコールのような水溶性のものと, ラノ リンやレシチンのような油溶性のものとがある。ポリオ キシエチレンの脂肪酸エステル, 脂肪アルコールエーテ ル，ラノリン誘導体などの界面活性剤も湿潤柔軟剤の 1 種として利用される。

そのほか皮膚の水分の吸收排出を調節すると考它られ るホスファチドを参考として, 脂肪アルコールおよび脂 肪アルコールのポリオキシエチレン誘導体の末端をリン 酸化したリン酸エステルが用いられることもある。

\section{むすび}

以上, 界面活性剤が化粧品工業に利用されている概況 につき, 乳化剤, 可溶化剂, 分散剤としての役割を中心 にして述べてきた。界面活性剤の発達により化粧品の品 質も向上し, 生産も能率化した。今後はますます多くの 界面活性剂が多くの目的で使用されることになるものと 思うが，界面活性剤を用いることによる問題点も少なく ない。界面活性剤が皮膚に及ぼす影響をはじめ，防腐㓮 の防腐効果に及ぼす影響や合成樹脂系容器に及ぼす影響 なども無視できない。これらの問題についてはほかに詳 細な報告もあるのでここでは省略した。

化粧品に界面活性剤を使用する立場から界面活性剤製 造メーカーに望みたいことはさらに性能のすぐれた界面 活性戍を開発することとともに

1）その性能が常に一定であってほしい。

界面活性剂は一般に分子量が大きく，重合による 製品が多いためか，化学恒数はよく合っていても乳
化特性や可溶化特性や製品のレオロジカルな特性に 及ぼす影響力などが異なり，しかもその差異が長期 の経日によって初めて明確になる場合がある。最近 は品質管理の発達により，孖なり品質は一定化して きたが，さらにロット間の差異や性能の経日変化な どが少ない製品にしていただきたい。

2）刺激，毒性についての保証が完全であること。

また化粧品は日々連続して使用されるものである から，皮膚に対する刺激が少しでもあってはならな いし，誤飲誤食の危険性もあるので，口に用いる化 粧品でなくても毒性の完全な保証が必要である。こ れらについては化粧品会社でも厳重な試験を行なっ ているが，化粧品原料としての界面活性剤を製造さ れる立場からも充分研究し, 完全な保証に基づいて 発売されたい。

3）においや色が少ないこと。

さらに化粧品はし好品的要素が強いので製品のに おいや色調は重要である。いかに高価な香料を用い ても原料臭によってそこなわれては意味がない。同 様に製品を目的とする色調に仕上げても，原料自体 の色調が経日により変化するよらでは無意味であ る。したがって，界面活性剤もそれ自体のにおいや 色調ができるだけ少なく，また経日変化の少ないも のでなければならない。 などである。

（昭和 44 年 5 月 22 日受理）

$$
\text { 文献 }
$$

1) R. Dorey “Emulsion Technology”, p. 119-26 (1946), Brooklyn, Chemical Publishing Co.

2) T. Mitsui, S. Tahara, Y. Machida, Proc. Sci. Sec. Toillet Goods Assoc., 46, 73-84 (1966), Dec.

3) J.L. van der Minne, P.H.J. Hermanie, J. Colloid Sci., 8, 38 (1953)

4) T. Mitsui, Am. Perfnmer \& Cosmetics, 80 (8), 238 (1965) 